\title{
The Effects of Ca Applications on Peach Fruit Mineral Content and
}

Quality.

J. Val*, E. Monge, and A. Blanco

Estación Experimental de Aula Dei (CSIC).

Avda. Montañana 1005

50059-Zaragoza, Spain
J.L. Espada

C. T. A. (DGA).

POBox 617.

50080-Zaragoza, Spain

Keywords: Prunus persica, calcium, Ca absorption, fruit physiopathies, fruit quality, peach.

\begin{abstract}
Late season peach cultivars are usually cold stored for a few weeks to extend the marketing season, but physiological disorders related to calcium deficiency are now emerging. To study the absorption of $\mathrm{Ca}$ by the peach fruit, adult trees of two late maturing cultivars: 'Miraflores' and 'Jesca' were treated with Ca applied in two different ways: either as foliar sprays of Ca water solutions, or rubbed on the fruit with a Tara gum gel containing the Ca solution. In both cases, the Ca source was $\mathrm{CaCl}_{2}$. Repeated foliar sprays along the growing season, of aqueous solutions of Ca concentrations ranging from 0.25 to $1 \%$ Ca did not affect the concentration of Ca in the peach skin or fruit flesh. Similarly, no effects on the fruit quality traits were observed at harvest. In a second experiment, fruits were rubbed with a calcium containing gel. A great increase in Ca concentration was found both on skin and flesh of fruits treated with $1 \%$ Ca. However, fruits treated with $1 \%$ Ca had a greater preharvest drop than the other treatments, and some fruit quality traits at harvest were affected, as flesh firmness which was smaller on both sides of the fruit, and fruit shape, which became more flat.
\end{abstract}

\section{INTRODUCTION}

Late season peach (Prunus persica (L.) Batsch.) cultivars are becoming increasingly profitable in Spain, for which the marketing period is being expanded for several weeks, by storing the fruits under cold conditions. These cultivars are grown in bags, in the "Bajo Aragón" area. This technique implies the use of bags to cover the fruits, and it is usually done in June after fruit thinning, leaving the bags on the fruits until harvest, for which these are sold as pesticide free. However, fruit physiological disorders are now emerging, which deteriorate the quality of fruits, and economic loses are beginning to occur. The main disorder to appear, the vitrescent dark spot, has rarely been described (Val, 2007). In short, areas of the fruit mesocarp become traslucent, and this is accompanied by a darkening of the area, with no external symptoms that become visible until long after fruit harvest.

The vitrescent dark spot observed in peaches is somehow similar to bitter pit, lenticel blotch pit and other physiological disorders of apples and other horticultural species, which have been related to calcium deficiency. In apple, Ca sprays have long been recommended to prevent the development of bitter pit and other disorders (Ferguson and Watkins, 1989; Saure, 2005) by increasing the concentration of Ca in the apple flesh. However, little success is generally achieved when spraying Ca to apple fruits, and this 
has been recently related to the small, if any, absorption of Ca through the apple skin (Val et al., 2008).

Recent work has shown that the low efficacy of Ca applications may be due to difficulties of the chemicals in passing through the fruit cuticle. The penetration of Casalts is dependant upon its point of deliquescence (POD) (Schönherr, 2001). $\mathrm{CaCl}_{2}$ is a Ca formulation with very low POD, for which is one of the best candidates to test the performance of Ca-treatments on peach fruits. Besides, Ca absorption is closely related to air humidity conditions, and these are usually very low under the Middle Ebro Valley growing conditions. To test the efficiency of Ca treatments during the fruit growth period, two preliminary experiments have been carried out on two late ripening peach cultivars, applying $\mathrm{CaCl}_{2}$ as an aqueous foliar spray, or mixed in Tara gum and rubbed on the fruit skin.

\section{MATERIALS AND METHODS}

Two experiments were performed in 2007, one in a 'Miraflores' orchard in Alfamén (Saragossa, Spain), the other in a 'Jesca' planting in Puigmoreno (Teruel, Spain), both places located in the Middle Ebro Valley.

In Alfamén, trees were sprayed with different concentrations of Ca (from 0.25 to $1 \% \mathrm{Ca}$ ) as $\mathrm{CaCl}_{2}$ solutions and compared to untreated controls. Treatments were applied as randomized blocks with 3 replications, and the tree was the experimental unit. The treatments were applied at monthly intervals from 10 May until 9 August, 2007.

In Puigmoreno, $\mathrm{CaCl}_{2}$ was mixed in Tara gum, to make 0.5 and $1 \%$ concentrations of $\mathrm{Ca}$, and the paste was rubbed on the fruits. These treatments were compared to fruits rubbed with the gum containing no $\mathrm{Ca}$, or with fruits left untreated. The experimental unit was single-tree and treatments were applied as randomized blocks with four replications. Fruits were treated late in the growing season, on 14 August, 2007, and were bagged again after the treatment application, following the general practice of the area.

At harvest, yield parameters and fruit quality traits were recorded, and samples of fruits were randomly selected for mineral element analysis. Skin and mesocarp were detached for separate analysis. Ca, Mg and K were analyzed with a Unicam 929 atomic absorption spectrophotometer.

Analysis of variance was carried out with data, and when significant effects were detected, means were analyzed using Duncan’s Multiple Range Test.

\section{RESULTS}

The application of Ca to 'Miraflores' peach trees resulted in foliar damage when a $1 \%$ concentration of Ca was sprayed to the trees, while no such effect was observed for lower concentrations. At harvest, (26 September) no differences in yield, number of fruits picked, or mean fruit size was recorded. Fruit quality also showed no significant differences for any of the parameters measured.

Analysis of mineral elements in the fruit skin and mesocarp showed that little, if any absorption of $\mathrm{Ca}$ had occurred (Table 1). No effects were also observed on $\mathrm{Mg}$ concentration, and only the concentration of $\mathrm{K}$ in the fruit skin of trees sprayed with $0.5 \%$ Ca was significantly greater than the concentration of untreated fruits or treated with the greatest concentration.

In Puigmoreno, the application of plain Tara gum to the peach fruits did not result in any significant effect for any of the parameters recorded. However, a greater preharvest drop of fruits was observed in 'Jesca' fruits treated with the 1\% Ca Gum mixture. 
However, at harvest, made on 23 October, no differences in fruit size were observed between the remaining fruits of this treatment, and those of other treatments.

Several fruit quality traits were affected by the Ca application treatments (Table 2). Fruit shape was affected, so that fruits rubbed with $0.5 \%$ Ca were less elongated than those untreated, while flesh firmness significantly decreased in fruits rubbed with $1 \% \mathrm{Ca}$. No effects of juice acidity or soluble solids were recorded.

Analysis of mineral elements in the fruit tissues showed that the application of $\mathrm{Ca}$ containing gum resulted in a significant increase in Ca concentration both in the peach mesocarp and skin (Table 3), particularly in fruits where a 1\% concentration of Ca had been applied. Mg concentration also significantly increased in the 1\% treated fruits, but only in the mesocarp, while K remained unaffected.

\section{DISCUSSION}

Late season peaches are increasingly demanded by the markets, and the marketing season is now being extended to mid-November. Thus, cold storage of late season peach fruits has become a general practice. The development of peach fruit physiopathologies is a rising economic problem when trying to extend the fruit marketing season (Val, 2007).

Ca sprays to peach fruits as an aqueous solution has shown to be as ineffective as it has proved to be in apple (Val et al., 2008), as no effects on the fruit quality parameters were found, and no effects on ion content in the peach skin or mesocarp recorded. Only a certain increase in $\mathrm{K}$ in the skin of peaches treated with $0.5 \% \mathrm{Ca}$. Besides, the great level of phytotoxicity found for the greater concentrations applied discourages the recommendation of such practice, particularly when high concentrations of Ca should be applied.

On the contrary, the treatment of $\mathrm{CaCl}_{2}$ incorporated in Tara gum to the fruits, and these bagged following the application, as usually performed in the area, resulted in a great increase in the absorption of Ca: up to a $261 \%$ in the mesocarp and $247 \%$ in the skin for the greatest concentration of Ca applied. However, at this concentration (1\%) a great increase in preharvest fruit drop was observed, which is an important damage, as late season peaches in Spain already have a particularly great natural preharvest drop, as most late ripening cling peaches. Also, the decrease in flesh firmness at harvest observed in the $1 \% \mathrm{Ca}$ treated fruits may deteriorate the quality value for marketing. Consequently, lower concentrations should be tested when evaluating the effect of Ca-treatments on the prevention of the development of fruit physiopathies in peach, as well as in other fruit species.

\section{CONCLUSIONS}

Ca treatments, applied as $\mathrm{CaCl}_{2}$, to peach fruits are far more effective when applied as a mixture in Tara gum, than when aqueous solution are sprayed on the peach tree canopy. A greater absorption of $\mathrm{Ca}$ has been found following such treatments and very few effects on fruit quality traits observed, whereas no effects have followed sprays of water solution of calcium to the tree canopy.

\section{ACLNOWLEDGEMENTS}

Work partially financed by DGA (PM005/2006) and by INIA (PET2007-09-COS02, Plan de Actuación Específico para Teruel) 


\section{Literature Cited}

Ferguson, I.B. and C.B. Watkins. 1989. Bitter pit in apple fruit. Horticultural Reviews. 11: 289-355.

Saure, M.C. 2005. Calcium translocation to fleshy fruit: its mechanism and endogenous control. Scientia Horticulturae. 105: 65-89.

Schönherr, J. 2001. Cuticular penetration of calcium salts: effects of humidity, anions, and adjuvants. Journal of Plant Nutrition and Soil Science. 164: 225-231.

Val, J. 2007. Calidad del melocotón de Aragón. Estudio de calciopatías (mancha vitrescente) por métodos convencionales, espectroscópicos y diagnóstico precoz. Nutri-fitos. 171: 87-98.

Val, J., E. Monge, D. Risco, and A. Blanco. 2008. Pre-harvest calcium sprays increase calcium concentrations in the skin, but not in the flesh, of apples. Journal of Plant Nutrition. (in press). 
Table 1 Concentrations of mineral elements (mg/100g FW) in fruits of 'Miraflores' peach trees sprayed at monthly intervals with different concentrations of $\mathrm{Ca}$ along the growing season.

\begin{tabular}{|c|c|c|c|c|c|c|}
\hline \multirow[t]{2}{*}{ Treatments } & \multicolumn{2}{|c|}{$\mathrm{Ca}$} & \multicolumn{2}{|c|}{$\mathrm{Mg}$} & \multicolumn{2}{|c|}{$\mathrm{K}$} \\
\hline & Mesocarp & Skin & Mesocarp & Skin & Mesocarp & Skin \\
\hline Control & 2.66 & 11.6 & 7.01 & 10.0 & 128.6 & $179.9 \mathrm{a}$ \\
\hline $0.25 \% \mathrm{Ca}$ & 1.91 & 13.1 & 7.01 & 10.2 & 119.1 & $\begin{array}{c}180.9 \\
\mathrm{ab}\end{array}$ \\
\hline $0.5 \% \mathrm{Ca}$ & 1.72 & 14.7 & 6.89 & 10.9 & 118.4 & $196.1 \mathrm{~b}$ \\
\hline $0.75 \% \mathrm{Ca}$ & 1.75 & 12.3 & 7.52 & 10.7 & 127.6 & $\begin{array}{c}182.6 \\
\mathrm{ab}\end{array}$ \\
\hline $1 \% \mathrm{Ca}$ & 2.23 & 14.6 & 7.09 & 10.3 & 125.1 & $170.7 \mathrm{a}$ \\
\hline signif & ns & ns & ns & ns & ns & * \\
\hline
\end{tabular}

ns, *: non significant or significant differences at $\mathrm{P} \leq 0.05$.

Within each column, values followed by same letter do not differ significantly at $\mathrm{P} \leq 0.05$.

Table 2.- Quality traits at harvest of 'Jesca' peaches rubbed with Tara gum containing different concentrations of $\mathrm{Ca}$ and compared to untreated fruits

\begin{tabular}{|c|c|c|c|c|c|c|}
\hline & \multirow[b]{2}{*}{$\begin{array}{l}\text { Fruit } \\
\text { side }\end{array}$} & \multirow[b]{2}{*}{$\begin{array}{l}\text { Untreated } \\
\text { fruits }\end{array}$} & \multicolumn{3}{|c|}{$\begin{array}{l}\text { Tara } \\
\text { gum }\end{array}$} & \multirow[b]{2}{*}{ signif. } \\
\hline & & & 0\% Ca & $\begin{array}{c}0.5 \% \\
\mathrm{Ca} \\
\end{array}$ & $1 \%$ Ca & \\
\hline Diameter (mm) & & 74.2 & 75.3 & 77.0 & 73.0 & ns \\
\hline $\mathrm{L} / \mathrm{D}$ & & $0.91 \mathrm{a}$ & $0.89 \mathrm{a}$ & $0.85 \mathrm{~b}$ & $0.88 a b$ & $* *$ \\
\hline Acidity (mg/L malic a.) & & 5.4 & 5.3 & 5.5 & 5.8 & ns \\
\hline \multirow[t]{2}{*}{ Firmness (N) } & Blushed & $53.1 \mathrm{a}$ & $52.5 \mathrm{a}$ & $44.8 \mathrm{ab}$ & $38.9 \mathrm{~b}$ & * \\
\hline & Shaded & $55.3 \mathrm{a}$ & $51.9 \mathrm{ab}$ & $48.0 \mathrm{ab}$ & $43.1 \mathrm{~b}$ & $*$ \\
\hline \multirow[t]{2}{*}{${ }^{\circ}$ Brix } & Blushed & 12.6 & 11.8 & 12.2 & 13.5 & ns \\
\hline & Shaded & 12.4 & 11.6 & 11.9 & 12.9 & ns \\
\hline
\end{tabular}

ns, *, **: non significant or significant differences at $\mathrm{P} \leq 0.05$ and $\mathrm{P} \leq 0.01$ respectively. Within each line, values followed by same letter do not differ significantly at $\mathrm{P} \leq 0.05$. 
Table 3.- Mineral element concentration (mg/100g FW) in the skin and mesocarp of 'Jesca' peaches rubbed with Tara gum containing two different concentrations of $\mathrm{Ca}$, and compared to untreated fruits.

\begin{tabular}{|c|c|c|c|c|c|c|}
\hline \multirow[t]{2}{*}{ Treatments } & \multicolumn{2}{|c|}{$\mathrm{Ca}$} & \multicolumn{2}{|c|}{ Mg } & \multicolumn{2}{|c|}{$\mathrm{K}$} \\
\hline & Mesocarp & Skin & Mesocarp & Skin & Mesocarp & Skin \\
\hline Untreated fruits & $2.12 \mathrm{a}$ & $15.6 \mathrm{a}$ & $6.46 \mathrm{a}$ & 14.6 & 47.6 & 208.6 \\
\hline 0\% Ca & $2.06 \mathrm{a}$ & $14.1 \mathrm{a}$ & $6.45 \mathrm{a}$ & 14.2 & 50.3 & 214.2 \\
\hline $0.5 \% \mathrm{Ca}$ & $3.50 \mathrm{~b}$ & $29.4 \mathrm{~b}$ & $6.61 \mathrm{a}$ & 14.1 & 41.9 & 208.9 \\
\hline $1 \% \mathrm{Ca}$ & $5.53 \mathrm{c}$ & $38.6 \mathrm{~b}$ & $7.42 \mathrm{~b}$ & 15.7 & 52.5 & 190.7 \\
\hline signif. & $* * *$ & $* *$ & $* *$ & ns & ns & ns \\
\hline
\end{tabular}

ns, *, **: non significant or significant differences at $\mathrm{P} \leq 0.05$ and $\mathrm{P} \leq 0.01$ respectively. Within each column, values followed by same letter do not differ significantly at $\mathrm{P} \leq 0.05$. 